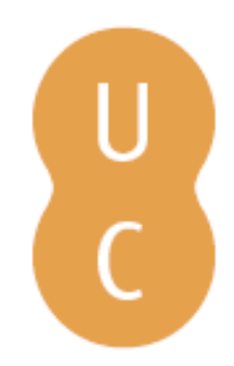

\title{
pombalina
}

\section{Romanitas e universalismo cristão: reflexões cristãs sobre o poder de Roma}

\author{
Autor(es): $\quad$ Dias, Paula Barata
}

Publicado por: Imprensa da Universidade de Coimbra

URL

persistente: URI:http://hdl.handle.net/10316.2/38947

DOI: $\quad$ DOI:http://dx.doi.org/10.14195/978-989-26-0395-7_1

Accessed : $\quad$ 26-Apr-2023 15:27:39

A navegação consulta e descarregamento dos títulos inseridos nas Bibliotecas Digitais UC Digitalis, UC Pombalina e UC Impactum, pressupõem a aceitação plena e sem reservas dos Termos e Condições de Uso destas Bibliotecas Digitais, disponíveis em https://digitalis.uc.pt/pt-pt/termos.

Conforme exposto nos referidos Termos e Condições de Uso, o descarregamento de títulos de acesso restrito requer uma licença válida de autorização devendo o utilizador aceder ao(s) documento(s) a partir de um endereço de IP da instituição detentora da supramencionada licença.

Ao utilizador é apenas permitido o descarregamento para uso pessoal, pelo que o emprego do(s) título(s) descarregado(s) para outro fim, designadamente comercial, carece de autorização do respetivo autor ou editor da obra.

Na medida em que todas as obras da UC Digitalis se encontram protegidas pelo Código do Direito de Autor e Direitos Conexos e demais legislação aplicável, toda a cópia, parcial ou total, deste documento, nos casos em que é legalmente admitida, deverá conter ou fazer-se acompanhar por este aviso.

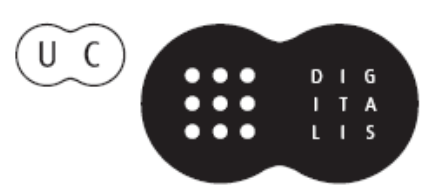




\title{
ROMANITAS E UNIVERSALISMO CRISTÃO - REFLEXÕES CRISTÃS SOBRE O PODER DE ROMA
}

\author{
Paula Barata Dias \\ (Universidade de Coimbra)
}

"Vnam omnium rem publicam agnoscimus, mundum"

Tertuliano, Apologeticum 38, 3.

INTRODUÇÃO

Nos anos finais do Império Romano, sujeito à pressão externa dos bárbaros, muitos romanos, questionando-se sobre as causas dos males, viam no abandono dos cultos religiosos tradicionais a culpa da catástrofe. Afinal, onde estava agora o Deus dos cristãos a que o Império, desde os tempos de Teodósio, aderira? Esta pergunta teve como resposta a obra bem conhecida $D e$ Ciuitate Dei de Agostinho de Hipona, vinte e dois livros iniciados após a pilhagem de Roma pelos Godos, em 410, terminados poucos anos antes de a própria Hipona de Agostinho sucumbir ao assalto Vândalo. Esta obra magistral, composta na maturidade da Idade do Ouro da Patrística', tornou-se exemplar para todos os que após ela buscaram reflectir sobre as relações entre a religião e o Estado, sobre a justiça e a responsabilidade humana e sobre o lugar do cristão enquanto peregrino e cidadão temporário da cidade terrena.

Santo Agostinho foi um dos autores que, nesta época, procuraram dar um sentido e fornecer uma explicação para os penosos acontecimentos que

${ }^{1}$ Angelo di Berardino ed., Patrologia, La Edad de Oro de La Literatura Patrística Latina, t. III, (ed. esp. BAC, Madrid, 1993) Inst. Patrístico Augustinianum, 1978, p. 431. "Tesis central de la obra es la providencia divina, que ilumina y guia la historia de la humanidad, dividida en dos ciudades (...) Agustin afronta y resuelve, com la luz de la razón y de la fe por eso es, a la vez, filosofia y teología - los grandes problemas de la historia". 
afligiam o Império, reflectindo sobre os acontecimentos passados e recentes de Roma $^{2}$. A necessidade de entender os acontecimentos que afectavam o Império mostra que os cristãos, particularmente as suas elites, estavam atentos e se preocupavam com o destino da sua cidade, com a qual se identificavam. Esta perspectiva compromete a imagem da indiferença pela decadência de Roma, ou mesmo da responsabilidade dos cristãos no curso dramático dos acontecimentos ${ }^{3}$. De facto, no final do séc. V, o império romano que feneceu e tombou, tendo pouco a ver com o seu passado pagão, era já um império cristão, pelo que, no caminho conjunto das duas esferas, houve etapas progressivas de harmonização ${ }^{4}$.

Assim, desde a primeira geração de cristãos surgiram vozes de identificação ${ }^{5}$ e relatos que expõem o propósito e as vantagens da integração

\footnotetext{
${ }^{2}$ Sobre o mesmo tema em S. Jerónimo, P. Barata Dias, "Testemunhos de identificação e de compromisso sobre a crise de Roma (séc. V) no Epistolário de S. Jerónimo", Biblos, Revista da FLUC, 2006, pp. 35-48.

${ }^{3}$ Edward Gibbon disse que a sua narrativa do declínio e queda de Roma descreve "o triunfo da barbárie e da superstição". A segunda parte deste binómio remete para o relevo do factor cristão na decadência de Roma. Uma leitura crítica do trabalho deste historiador do séc. XVIII em J. G. A. Pocock, "Gibbon's Decline and Fall and the World View of the Late Enlightenment", Eighteenth-Century Studies, 10, 3, 1977, pp. 287-303. Também A. R. Hands, "The fall of the Roman Empire in the west: a case of Suicide or Force Majeure?", Greece and Rome 10, 1963, pp. 153-168.

${ }^{4}$ É. Trocmé, "Porquoi le christianisme est-il devenu romain?", Ktema, 17, 1992, pp. 297-304. $\mathrm{O}$ autor questiona o motivo pelo qual, apesar das suas origens judaicas, o cristianismo se integrou tão rapidamente nas estruturas greco-romanas, processo que ele considera ter durado três gerações apenas. Atribui a responsabilidade desta evolução surpreendente à missão promotora de alguns agentes como Paulo, que arrastaram com eles toda uma população judeo-cristã que, sem esse impulso, ter-se-ia mantido na periferia. Trata-se de uma reflexão válida sobre as origens e o enquadramento social do cristianismo, mas levantamos algumas objecções: em primeiro lugar, o corpo doutrinal e teológico do cristianismo não depende exclusivamente da matriz judaica, na medida em que foi sendo construído já em ambientes profundamente helenizados. Além disso há que contar com a diferença instalada entre a matriz judaica o e cristianismo que se tornou maior após a destruição de Jerusalém em 70 d.C.

5 As cartas paulinas foram os primeiros textos neo-testamentários a ser escritos. $\mathrm{O}$ próprio Paulo estava consciente das vantagens que lhe advinham, como cidadão romano, para o seu trabalho de evangelização Assim na abertura da carta que dirige aos romanos, afirma-se como um produto da variedade cultural possibilitada por Roma. Neste passo, o termo 'bárbaros' aplica-se aos judeus não falantes de Grego, afinal a matriz judaica em que nasceu o cristianismo. Cf. Trad. portuguesa da Biblia Sagrada, Difusora Bíblica dos missionários Capuchinhos, Lisboa, 1984: (Rom. 1, 14 "Eu sou devedor tanto a Gregos como a Bárbaros, tanto a sábios como a ignorantes". (1 Rom. 13, 1-7) Neste importante passo, Paulo estabelece o princípio da cooperação e da convivência entre os cristãos e a autoridade política instalada. Está também presente o intertexto evangélico na referência ao poder político como uma delegação divina (Jo. 19 10-11); e no princípio da independência entre as obrigações politicas e religiosas (Mt. 22 15-22 "...a César o que é de César".
} 
pacífica na sociedade greco-romana, reconhecida como autoridade legítima a quem os cristãos devem colaboração.

Os lamentos comovidos de S. Jerónimo pelo fim de Roma e a reflexão que Santo Agostinho conduziu na sua obra poderão ser portanto interpretados mais como termos de chegada lógica de uma tendência de pensamento fundada já na história do cristianismo do que como novidades no âmbito da produção literária cristã ou como exclusivamente motivadas pelo direito de resposta às acusações dos pagãos ${ }^{6}$. É, pois, objectivo deste trabalho ilustrar a precocidade do propósito de conciliação entre os interesses do cristianismo e de Roma e também explorar algumas das motivações deste tipo particular de consciência histórica desenvolvida na reflexão cristã.

Considerar os aspectos da aproximação, convivência e identificação entre os interesses do cristianismo como realidade histórica emergente e o império romano que o envolvia não tem sido frequente, particularmente quando o âmbito de análise recua para a fase anterior à $P a x$ constantiniana. $\mathrm{O}$ estatuto de religião suspeita aos olhos das autoridades e da opinião pública e a realidade histórica das perseguições conduziram legitimamente as atenções dos investigadores para a análise dos confrontos e das diferenças entre os dois pólos?.

\footnotetext{
"Submeta-se cada qual às autoridades constituídas. Pois não há autoridade que não tenha sido constituida por Deus e as que existem foram estabelecidas por ele. Quem resiste, pois, à autoridade, opõe-se à ordem estabelecida por Deus (...) Os governantes não são de temer, quando se pratica o bem, mas quando se pratica o mal. Queres viver sem medo da autoridade? Pratica o bem e terás a sua aprovação, pois ela é o instrumento de Deus para o bem (..) É por isso também que vós pagais os impostos porque se trata de funcionários de Deus que nisso mesmo servem. Pagai, pois, a todos o que lhes é devido: a quem se deve o imposto, o imposto; a quem se deve a contribuição, a contribuição; a quem se deve a reverência, a reverência; a quem se deve a honra, a honra". Na 1Tim. 2, 1-4, Paulo recomenda que se reze "por todos os homens, pelos reis e por todos os que detêm a autoridade, para que possamos ter uma vida de paz e tranquilidade".

${ }^{6}$ W. R. Jones, "The Image of the barbarian in Medieval Europe", Comparative Studies in Society and History, 13, 4, 1971, pp. 376-407, p. 382: "Despite his ingenious effort to elevate contemporary discussions of the fate of Rome from merely historical level to metaphysical, and despite his insistence on the relative unimportance of the barbarian sacking of Rome against the backdrop of god's plan of redemption, he continued to contrast Roman civilization and barbarism in the conventional manner".

7 Tácito, Annales 15, 39-43; Suetónio, Vitae XII Caesarum 16, 2, os dois sobre a primeira perseguição, a de Nero, e a opinião pública contra os cristão no séc. I; Plínio o Moço, Epistolae 10, 96-97, relata a Trajano as perturbações da ordem geradas pela
} 
A remissão para segundo plano desta linha de análise está fundamentada na própria novidade evangélica do universalismo cristão, religião que, de modo revolucionário para os padrões da época, pregou a nulidade para a fé de fronteiras de cidade, tribo, género ou estatuto social ${ }^{8}$. Mensagens de identificação com os interesses de Roma não seriam o tom adequado a adoptar por parte de uma Igreja emergente, em busca de um lugar na comunidade, de identidade própria e com propósitos de expansão, que colhia frutos visíveis do impacto gerado pelo discurso da diferença e do confronto. As actas dos martírios, a apologética cristã dos tempos pré-constantinianos e mesmo a polemística contra os pagãos produzem e exploram uma retórica de incompatibilidade?

Assim os cristãos cooperam com os interesses de Roma, mas preparam-se com afinco para uma realidade maior. Roma não é um fim em si, é a circunstância que envolve o cristão, atento a uma dimensão mais vasta:

\begin{abstract}
"A paixão pela glória e pelas honras e pelos contactos sociais deixa-nos indiferentes, nada nos é mais estranho do que o envolvimento em assuntos públicos. Só conhecemos uma república para todos, o mundo"10.
\end{abstract}

desconfiança pública acerca dos cristãos. A acusação de Odium humani generis; de levarem a cabo rituais sinistros; de não cooperarem com as autoridades nem prestarem culto ao imperador tornaram-se lugares comuns da "diabolização" dos cristãos. Marco Aurélio Frontão, em cartas ao Imperador Marco Aurélio (139 d.C.), descreve as superstições e a perigosidade associadas ao cristianismo (C.R.W. Heinemann, The Correspondance of Marcus Cornelius Fronto with Marcus Aurelius Antoninus, Lucius Verus Pius and Various Friends, Loeb 112-113, Cambridge Harvard University Press, 1962-1963) e Celso, em 178, escreve o tratado De Vera Doctrina, em que refuta as crenças cristãs com base na razão (L. A. Rougier, Celse Contre les Chrétiens. La réaction païenne sous l'Empire Romain, Paris, 1977, Texte integral du Discours Vrai de Celse pp. 181-241).

${ }^{8}$ Esta missão universalista da Igreja aparece claramente após a Ressurreição (Mt 28,

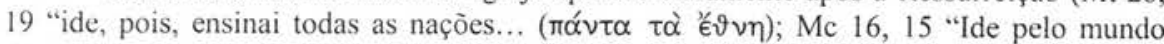

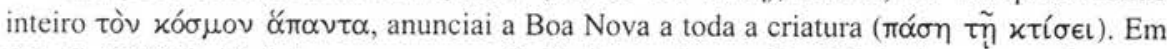
Gal. 3, 28 "Não há judeu nem grego...", Paulo proclama a igualdade de todos os homens para o cristianismo. Citamos a edição do $N T$ em Grego a partir de Nestle-Aland, Novum Testamentum Graece, Deutsche Bibelgesllschaft, Stuttgart, $1994^{22}$.

${ }^{9}$ Tertuliano, no seu Apologético, defende os cristãos da acusação de desinteresse pela participaçào na vida pública invocando o universalismo da mensagem cristã. Estes textos contam-se entre os primeiros sub-géneros da literatura cristã, e são uma fonte preciosa de informação sobre a presença cristã num universo pagão e o tipo de tensões geradas entre os dois grupos. Deve, no entanto, fazer-se a ressalva de que estes textos eram escritos expressamente para serem usados na edificação das comunidades ou na acção proselítica, o que os compromete quanto à objectividade da informação. Ver A. di Berardino, Patrologia op. cit. t. I, pp. 177-250.

${ }^{10}$ Op. cit. $38,3-4$. A tradução é nossa. At enim nobis ab omni gloriae et dignitatis ardore frigentibus nulla est necessitas coetus nec ulla magis res aliena quam publica. Vnam omnium rem publicam agnoscimus, mundum. 
Tertuliano acolheu, neste passo, a mensagem evangélica da universalidade cristã, religião destinada a abolir na terra as fronteiras entre os povos e a reuni-los numa só nação de crentes, e usa-a como justificação para os limites no envolvimento dos cristãos nos interesses de Roma. Aqui estará uma das explicações para o facto de a história oficial ter preservado uma imagem de oposição, de combate e mesmo de intolerância entre as propostas de vida cristãs e a civilização greco-romana, imagem esta que é a que domina para os primeiros quatro séculos de contacto entre as duas realidades, ou não fosse a época pós-constantiniana nomeada pelo expressivo termo de Pax.

Mas seria realmente esse o pensar dominante, ou estes textos devem ser também observados na sua intencionalidade, ofuscando porventura uma realidade mais serena, mas menos eficaz como arma de propaganda? De facto, quando o Imperador Teodósio proclama cristão o império romano, fá-lo reconhecendo uma situação de facto, que era a da cristianização maciça das cidades, dos elementos que serviam a administração e da justiça, dos agentes da própria cultura, enfim, das estruturas sociais que sustentavam o modo de vida romano, pelo que se tornava impossível para qualquer Estado manter a hostilidade contra a imensa maioria. Essa caminhada foi em grande medida silenciosa e fluida, nela tendo participado populações urbanas de diversas origens sócio-económicas, em estados de conversão diversos, mas cuja vida se desenrolava no enquadramento institucional fornecido pelo império romano, ou seja, com interesses directos na conservação da cidade antiga.

A língua de comunicação como reflexo profundo das identidades também pode fornecer dados preciosos quanto à capacidade de fusão entre a matriz greco-latina do Império romano e o cristianismo como realidade espiritual e temporal. Assim, os estudos de filologia, particularmente desenvolvidos pela escola holandesa de Nimega em meados do século passado, vieram expor as particularidades do Latim Cristão, visto como uma língua especial segundo critérios sociolinguísticos. Isto é, o Latim Cristão seria o tipo especial de latim usado por um grupo por razões de coesão interna, de criação de identidades afectivas, da necessidade de segurança e de segredo, da criação de novas realidades, como de uma liturgia própria. Estes esforços levaram a um conhecimento analítico do léxico, da morfossintaxe, da estilística e da retórica característica dos escritos cristãos, análise que foi projectada como o que seria possível conhecer da comunicação dos cristãos entre si e com a comunidade alargada, e mesmo do uso real da língua na oralidade ${ }^{11}$. No entanto, os pressupostos desta

"C. Mohrmann, "Quelques traits caractéristiques du latin chrétien», Miscellanea Mercati I, Vaticano, 1946, p. 437-466; Id. "Le latin commun et le latin des chrétiens», 
análise foram questionados em investigações mais recentes, que puseram em causa a concepção da língua dos cristãos como uma realidade estanque. Os que nasciam cristãos ou os que se tornavam cristãos viviam na comunidade sujeitos a interacções várias, nomeadamente as que decorrem das necessidades e dos interesses pragmáticos da vida quotidiana, pelo que mantiveram largamente preservado o património linguístico comum do meio em que interagiam. Assim, encontram-se os mesmos recursos linguísticos em autores cristãos e pagãos, ainda que se faça sentir a especificidade cristã no vocabulário e na presença do intertexto bíblico ${ }^{12}$.

É geralmente aceite que a expansão romana se fez acompanhar de procedimentos de integração percebidos como positivos, mesmo pelos membros de culturas vencidas, que referiram os beneficios, em termos de progresso e de civilização, associados à pertença ao Império Romano ${ }^{13}$. Antecedentes desta atitude favorável à integração sob um poder centralizado podem ser vistos no imperialismo macedónico de Alexandre o Grande, que projectou o mundo civilizado numa Oikouméne, uma comunidade alargada como modelo de civilização oposto não só ao sistema fragmentado das póleis gregas mas também ao velho antagonismo, de conotações éticas, étnicas e culturais, entre civilização grega e povos bárbaros. No caso helenístico, contudo, podemos afirmar que a filosofia superou a experiência política concreta, que como sabemos, apesar de ter deixado frutos colhidos sobretudo pelo império romano, não sobreviveu a Alexandre ${ }^{14}$.

Vigilia Christiana 1, 1947, pp. 1-12, Id. «Les éléments vulgaires du latin des chrétiens», Vigilia Christiana 2, 1948, pp. 89-101; pp. 162-184. B. I. Knott, "The Christian «special language» in the inscriptions", Vigilia Christiana 10, 1956, pp. 65-79.

12 Vincenzo Loi, Origini e caratteristiche della latinità cristiana, Bolletino dei Classici, Academia Nazionale dei Lincei 1978, 58 pp.

${ }_{13}$ Walter Goffart, "Rome, Constantinople and the Barbarians", The American Historical Review, 86, 1981, pp. 275-306, 280: "It is not as though Rome lacked powers of assimilation. In the many centuries since it had entered upon the conquest of distant lands, millions of barbarians had been pacified and absorbed into a common civilization, a Romania whose component peoples, however imperfectly homogeneous, looked the emperor for defense against outsiders and had no desire for liberation from this rule".

${ }^{14}$ R. W. Mathisen, "Peregrini, Barbari and Ciues Romani: Concepts of Citizenship and the legal Identity of Barbarians in the Later Roman Empire, The American Historical Review, 111, 4, 2006, pp. 1011-1040, 1012 "The concepts of cosmopolitanism and world citizenship go back at least to Hellenistic philosophies of the fourth and third centuries". Esta reflexão coube particularmente à escola estóica e aos cínicos, onde despontam o cínico 
Em plena Época Republicana, no séc. II, no auge do processo da absorção dos reinos helenísticos por Roma, Políbio encontra motivação para compor as suas Histórias na ascensão meteórica de Roma como único império ${ }^{15}$.

Estrabão, Geógrafo originário da Ásia Menor do séc. I d.C., pode constituir um exemplo desta aceitação pacífica dos resultados da expansão política romana, que são referidos no livro II da sua obra como fazendo parte da harmonia física, humana e política de que o continente europeu auferia, quando comparado com outras regiões menos dotadas destas qualidades pela natureza ${ }^{16}$. Assim, os diferentes povos em contacto com os romanos adoptavam o latim, a toga, as leis, os costumes e a religião romana, ao mesmo tempo que cediam os seus territórios ao poder e influência romanos, isto é, à presença, em variados graus, da administração, dos exércitos e mesmo de colonos originários da potência dominante.

Diógenes, que no séc. III se definiu a si próprio como um kosmopolites "um cidadão do mundo". Epicteto, já no Império romano, falará também de si mesmo como um "cidadão do mundo" (Diógenes Laércio, Vidas e Opiniões dos Filósofos antigos, 6. 63); Epicteto, Discursos 2.10.1).

${ }^{15}$ Políbio, Histórias 1. 7 “...Os romanos subjugaram, não algumas partes, mas quase toda a terra habitada, e deixaram um poderio tão vasto que é impossível aos nossos contemporâneos resistir-lhe, e aos nossos descendentes, excedê-lo", (trad. port. in M. H. da Rocha Pereira, Romana, Antologia da Cultura Latina, Universidade de Coimbra, 2000, apêndice, p. 267).

${ }^{16}$ Estrabão, Geografia, livro II 5-26 ( in M. H. da Rocha Pereira, Hélade, Antologia da Cultura Grega, $9^{\mathrm{a}}$ ed., Asa, Porto, 2005, p. 497). De matriz cultural grega, Estrabão vê o mundo segundo um olhar romano. Assim, considera inabitável a Europa Setentrional, aquela que está mais sujeita ao frio, o que constitui de facto o limite natural da expansão romana no norte. A Europa é descrita como sendo um continente de extraordinária variedade "dotada de uma admirável natureza pelo que toca à excelência dos homens e da administração pública". Num texto cuja linha de força é a descrição física e humana da Europa, Estrabão aflora a intervenção grega e particularmente a romana no espaço europeu. Enquanto dos Gregos se releva a sua aptidão na arte de viver, com uma organização política e técnica que permitiu aproveitar um território mais difícil "um pais de montanhas e rochas", já os romanos, são projectados de acordo com o seu processo histórico de expansão, entendido na sua missão civilizadora e criadora de uma comunidade de povos em contacto: "os romanos conquistaram muitos povos que eram por natureza selvagens, devido aos lugares que habitavam, por serem acidentados ou desprovidos de portos, ou gelados, ou, por qualquer outra razão, impróprios para albergar muita gente, e assim puseram em contacto uns com os outros quem tinha vivido isolado, e ensinaram povos mais selvagens a viver em sociedade". Os condicionalismos naturais, climáticos ou orográficos, responsáveis, pela variedade da paisagem europeia, explicam a mistura entre povos dados ao conflito e à guerra - nas regiões mais inóspitas- e povos dados à paz e à agricultura. Estes sobrepõem-se naturalmente, porque "Dos dois elementos, é mais numeroso o que é dado à paz, de modo que esse domina; sob a égide dos povos condutores - outrora os Gregos, mais tarde os Macedónios, e os Romanos..." 
Mesmo entre os judeus, reconhecidos pelo seu carácter independente, um dos primeiros testemunhos bíblicos sobre Roma, retirado do I livro dos Macabeus, ofereceu dos romanos uma imagem positiva ${ }^{17}$. Também após a tomada de Jerusalém por Pompeu em 63 a.C., altura em que se consolidou na Palestina a resistência ao poderio romano, Fílon de Alexandria, judeu helenizado participante numa embaixada ao imperador Caio Calígula pelo ano 40 , descreveu de modo encomiástico as vantagens de pertencer ao Império romano $^{18}$.

Os romanos, sobretudo os do final da República e dos inícios do Império, apresentaram de si próprios uma descrição que os legitimava como povo destinado a governar, quer no discurso histórico, em que o homem e os

17 I Mac 8 1-11. Citamos o AT a partir de A. Rahlfs, Septuaginta, Deutsche Biblegesellschaft, Stuttgart, 2004. Judas preparou uma embaixada para estabelecer uma aliança com os romanos. O ressentimento contra Antíoco Epifânio levou a que o retrato destes fosse idealizado, por contraponto ao inimigo comum, os Gregos. O autor descreve a República Romana, o senado e a magistratura consular. "Chegou aos ouvidos de Judas a fama dos romanos, que eram extremamente poderosos, mostravam-se benevolentes para com os seus aliados e ofereciam a sua amizade a todos os que a eles recorriam. Falaram-lhe também das suas façanhas na Galácia, que eles venceram, e de tudo o que fizeram na Hispânia, onde se apoderaram das minas de prata e de ouro que ali havia, conquistando todo

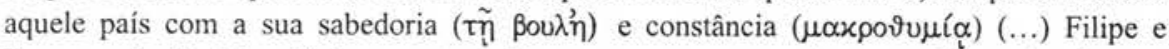
Perseu, reis da Macedónia, e outros, levantaram-se contra eles, mas foram igualmente derrotados e subjugados. (...) Arruinaram, igualmente, e subjugaram ao seu domínio os outros reinos e ilhas que lhes resistiram. Mas conservaram a sua fidelidade aos seus amigos e aliados, estendiam o seu poder sobre reinos vizinhos ou distantes, e todos os que ouviam pronunciar o seu nome, temiam-nos (...) Apesar de tudo isto, nenhum deles trazia diadema, nem se vestia de púrpura, para se engrandecer. Constituíram um conselho supremo, onde, cada dia, trezentos e vinte conselheiros discutiam os assuntos do povo, para bem o governar ( $\epsilon \dot{u} \varkappa \sigma \mu \tilde{\epsilon} \boldsymbol{i} \nu$ ). Cada ano confiavam a autoridade suprema a um homem só, que dominava em todo o território e todos obedeciam a este homem único, sem que houvesse, entre eles, inveja ou ciúme..."

${ }_{18}$ Philo of Alexandria, On the Embassy to Gaius (A. Colson w. Earp eds.), Loeb Classical Library, $1962, \mathrm{n}^{\circ} 379,8 ; 10 ; 147$, p. 4 . Apresentamos a nossa tradução para português "império que rejeita as divisões, governado por boas leis e em que todas as regiões, do Oriente ao Ocidente, do Sul ao Norte se unem num conjunto harmonioso (Élৎ tò

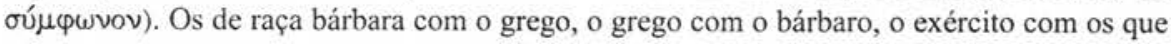
habitam as cidades, os cidadãos com o exército, para usufruirem em comum da paz (...) um Império, não sobre a maior parte das regiões do mundo, mas sobre o que se pode chamar de

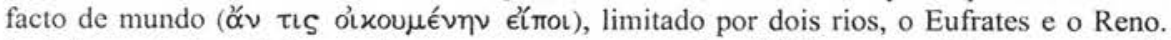
(...) Por estes beneficios se alegra o povo romano, toda a Itália, mas também os povos da Ásia e da Europa. ( $\$ 147$, falando de Caio Calígula) "ele libertou o mar de navios piratas e encheu-o de navios mercantes, trouxe a liberdade a todas as cidades, converteu a desordem

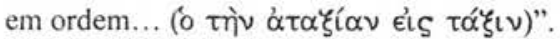


sucessos do presente se harmonizam com as virtudes já exibidas no passado, quer no discurso filosófico, quando está em causa a crítica de modelos políticos. Salústio, por exemplo, descreveu as origens de Roma como resultado de um movimento de sedentarização e de uma etnogénese variada. Os romanos resultaram da fusão de povos de origem diferente, alguns vindos de longe (ao contrário dos atenienses cuja origem lendária os definia como "autóctones", os que brotaram do solo). Os Troianos, sob comando de Eneias, com os habitantes locais, os "aborígenes, raça selvagem de homens sem leis nem governo, livre e alodial", juntaram-se, graças à concórdia, dentro das mesmas muralhas para formar uma cidade. Esta cresceu em número de cidadãos, em recursos e em regras, e despertou nos povos vizinhos a inveja. A coragem, a capacidade de previsão e a motivação em proteger a libertas, patria, parentes levaram os romanos à vitória, numa guerra essencialmente defensiva. Numa segunda fase, justificaram-se os combates ofensivos, mas com o fito de proteger amigos e aliados. Assim, os romanos "contraíam amizades, mais por conferirem benefícios do que por os receberem". Também Tito Livio apresentou as qualidades intrínsecas do povo romano enquanto entidade colectiva a animar os primórdios da história romana. Estes heróis possuíam um carácter modelar que, passado ao registo histórico, pode inspirar, pelos bons e maus exemplos, as gerações vindouras ${ }^{19}$.

No relato ciceroniano presente em $A$ República, a identidade romana é colocada em confronto com as características de outros impérios rivais. Surge, portanto, a revisão do conceito de bárbaro originalmente definido no mundo grego sob critérios étnicos e linguísticos, e desponta o conceito de bárbaro em termos de qualidades éticas ${ }^{20}$. A vocação dos romanos para construir um Estado duradouro surgiu logo na presciência providencial do fundador, que

${ }^{19}$ Salústio, Catilina 6 1-5, (in M. H. da Rocha Pereira, Romana, Antologia da cultura Latina, Universidade de Coimbra, 2000, p. 100) “...O que há de mais salutar e fecundo no estudo da História é que se contemplam os ensinamentos de toda a espécie de exemplos dispostos num momento bem visível; dai se podem extrair modelos a imitar para uso próprio e do seu pais, e actos vergonhosos a evitar (...). De resto, (...) jamais algum país foi maior, mais puro, mais rico em bons exemplos nem levaram tanto tempo a entrar numa cidade a avareza e o luxo, nem a tal ponto nem durante tanto tempo a pobreza e a parcimónia ocuparam lugar de honra". Tito Lívio, Ab Vrbe Condita Libri XX, prefácio 6-7; 10-11, (o M. H. da Rocha Pereira, op. cit., p. 209)

${ }^{20}$ Cícero, A República, I 37.58 (M. H. da Rocha Pereira, op. cit., p. 35). À pergunta de Lélio sobre se Rómulo pode ser classificado como um soberano bárbaro, Cipião assume com objectividade o confronto com a noção grega do conceito: "se, como dizem os Gregos, todos os povos ou são gregos ou são bárbaros, temo que ele tenha sido rei dos bárbaros. Mas, pelo contrário, se esse nome se aplicar aos costumes e não às línguas, entendo que os Romanos não são mais bárbaros do que os Gregos." 
orientou a escolha do local ideal para fundar a cidade por critérios claramente políticos $^{21}$. A superioridade da constituição da República romana desponta quando comparada com outras cidades e obras de legisladores do mundo grego, porque, ao contrário destas, criadas por um só e sujeitas à mudança abrupta, a fórmula romana evoluiu gradualmente e surgiu do empenho colectivo ${ }^{22}$.

Todavia, partiu também do próprio Cícero uma reflexão sobre a vastidão temporal e espacial do universo, diante da qual a fama e os actos dos romanos se relativizam. A consciência dos limites da gloriosa aventura romana na terra fez-se ouvir no passo de $A$ República conhecido como $O$ Sonho de Cipião ${ }^{23}$. Há, portanto, segundo o Romano que venceu Cartago, que procurar a realização e a glória noutros valores para além dos resultados do exercício do poder político ou militar. Mais do que as implicações filosóficas do texto, reparemos que a concepção de que o poder exercido pelos romanos não tinha um valor absoluto se encontra já na reflexão romana. Também com Octávio César Augusto, a Pax Romana emergiu como uma missão de que o império se encarregava. Governar e impor a ordem era um labor para os romanos e um beneficio para os povos dominados ${ }^{24}$.

Este papel providencial de que os romanos se sentem investidos como guardiães da ordem e da paz foi particularmente reconhecido pelos apologetas cristãos que procuravam, nos tempos atribulados das perseguições, tornar clara às autoridades, à opinião pública e aos intelectuais a sua identificação com a

${ }^{21}$ Cícero, República, II. 3. 5, (in M. H. da Rocha Pereira op. cit. p. 37) falando de Rómulo: “....este varão dotado de excelsa prudência teve a visão de compreender que a localização no litoral não é a mais conveniente para cidades destinadas a serem o centro de impérios duradouros...".

${ }^{22}$ Cícero, A República, II 1.2 (id., ibid.). Depois de referir Minos de Creta, Licurgo de Esparta, e Teseu, Drácon, Sólon, Clístenes e Demétrio de Faléron como exemplos de legisladores do passado, refere a originalidade da fórmula romana, “....ao passo que a nossa República não saíra do engenho de um só, mas de muitos, e não foi constituída apenas na vida de um homem, mas durante séculos e gerações".

${ }^{23}$ Cícero, A República VI, 19-20 (id., p. 44-45): "Vês que a terra é habitada em sítios dispersos e estreitos, e nessa espécie de manchas onde há gente, ficam intervaladas vastas solidões, e aqueles que habitam a terra estão não só isolados, de tal modo que entre eles não pode haver comunicação de uns para outros, (...) Pois toda a terra em que morais, que estreitece nos pólos e se alarga mais dos lados, é uma bem pequena ilha. (...) Acaso nesta mesma terra habitada e conhecida o teu nome ou o de qualquer de nós pôde ultrapassar o Cáucaso que vês aqui ou atravessar o Ganges, acolá? (...) Tira essas regiões e verás sem dúvida em que estreiteza de limites a vossa glória (i. e. a glória romana) pretende dilatar-se".

${ }^{24}$ Virgílio, Eneida VI 847-853. A missão romana de regere imperio populos (...) pacique imponere morem/ parcere subiectis e debellare superbos reflecte a ideologia augustana dominante de que o exercício do poder do chefe é um serviço, um labor, e de que os romanos estão incumbidos de uma missão civilizadora. 
estabilidade do Império. Desta forma, surgem discursos muito semelhantes aos que foram produzidos antes, quer por romanos, quer por não romanos em paz com o domínio romano.

Assim, trazemos dois exemplos convergentes na interpretação que fazem de um momento crucial do passado, o início do império para os romanos e da Revelação para os cristãos. Nos finais do séc. III, Orígenes respondia com oito livros às críticas que o filósofo pagão Celso fizera do cristianismo. Este advogava que o cristianismo enfermava de erros teológicos, de contradições e de superstições, não trouxera novidade, já que muito do que defende tinha sido enunciado por filósofos platónicos, e, sobretudo, que se tratava de uma religião que alienava os seus praticantes da razão e dos interesses públicos. Refutando este último ponto, Orígenes alega que a fortuna de Roma no séc. I obedeceu ao plano divino de preparar o mundo para a vinda do cristianismo. Depois de citar o salmo 72, 7 "Em seus dias florescerá a justiça, grande será a paz", diz:

Preparou Deus as nações para receberem a sua mensagem, submetendo-as a todas ao Imperador único de Roma, impedindo que o isolamento das nações causado pela pluralidade dos reinos tornasse mais difícil aos apóstolos a execução do que Cristo determinou: -"Ide, e ensinai todos os povos (Mt 28, 19). É pois claro que Jesus

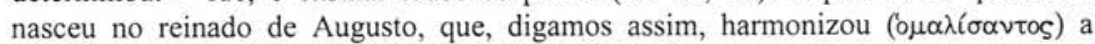
maior parte dos homens da terra num só império ${ }^{25}$.

Também Eusébio de Cesareia, leitor de Orígenes, se manifestou sobre o tema, ao defender que existe uma afinidade lógica entre um império romano, sujeito a um só imperador e uma Igreja de um só Deus. Destaca também o significado providencial de o nascimento de Jesus ter coincidido com o governo de Augusto. Assim, foi por determinação divina que o cristianismo nasceu numa época de paz e de estabilidade universal sob os romanos, porque deste modo pode cumprir a sua missão de chegar a todos os povos:

...em menhuma outra época, a não ser precisamente na do tempo de Cristo, esteve a

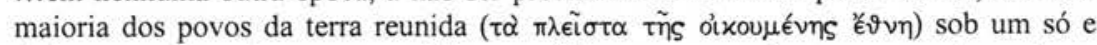
único governo, o dos romanos. Foi, com efeito, na mesma época em que Jesus dava, de modo inesperado, a sua entrada no mundo dos homens que o poder romano estava no seu apogeu. Augusto alcançava o poder absoluto ('Aưoú sobre quase todas as nações, enquanto Cleópatra era reduzida ao cativeiro e se extinguia no Egipto a dinastia dos Ptolomeus. Desde esse dia até hoje está desaparecido esse império do Egipto, que existiu desde sempre (...). Depois disso, também o povo dos judeus caiu sob o jugo dos romanos, tal como os sírios, os capadócios, os macedónios, os habitantes da Bitínia e os gregos, (...) Convém imaginar as

${ }^{25}$ Origenes, Contra Celsum Libri VIII, cap. 72, PG 11 col. 1627 (inc. col. 1521). 
dificuldades que teriam sentido os discípulos, se se tivessem deslocado por entre tantos povos divididos e hostis, isolados uns dos outros, sem a mínima comunicação e

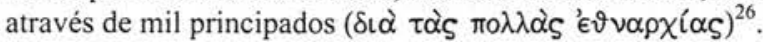

Tertuliano focou antes de Orígenes e de Eusébio este carácter providencial da conjugação dos interesses de Roma e dos cristãos. Unificados pelo desejo de paz, as autoridades não têm de temer traições ou sedições vindas dos cristãos, porque estes agem e rezam pela salvação do império. Autor africano dos finais do séc. II e pioneiro das letras cristãs latinas, de carácter forte e aguerrido, no seu Apologeticum mostrou-se influenciado pelo espírito milenarista, o que, numa primeira análise, poderia tornar mais ténue o seu interesse na conservação do poderio de Roma. $\mathrm{Na}$ verdade, veremos que este fundo milenarista constitui em Tertuliano uma razão para reforçar o empenho dos cristãos no apoio ao modelo imperial romano. Assim, respondendo à acusação de que os cristãos se alheavam quanto ao destino do imperador, ao recusarem praticar sacrifícios em sua honra (Qui ergo putaueris nihil nos de salute Caesarum curare), deixou claro que os governantes estão incluídos nas preces dos cristãos, pois isso mesmo foi determinado pelos apóstolos ${ }^{27}$. Na verdade, a conservação da paz é o desejo universal, e os cristãos partilham com todos os homens desse interesse.

Nós, de facto, apelamos ao Deus eterno, ao Deus verdadeiro, ao Deus vivo pela salvação do imperador, (...) porque é do coração que rezamos, e imploramos sem cessar por todos os imperadores, para que tenham uma vida longa, um governo tranquilo, uma morada segura, um exército forte, um senado fiel, um povo honesto, um mundo em paz, enfim, tudo o que um homem ou um imperador pode desejar ${ }^{28}$.

Além do preceito evangélico e do interesse universal pela paz, os cristãos têm uma razão ainda mais forte para rezar pelo imperador e pela estabilidade do império. O fim do mundo, a terrível catástrofe que a todos ameaça, está

${ }^{26}$ Eusébio de Cesareia, Demonstrationis Euangelicae Libri X, PG 22, III, 7, col. 245 (inc. col. 11). Nascido na $2^{\mathrm{a}}$ metade do séc. III, participou no Concílio de Niceia, foi também autor de uma biografia de Constantino e de uma obra panegírica, os Laudes Constantini. Considerava a monarquia do primeiro imperador cristão como uma bênção para todo o Império.

${ }^{27}$ Tertuliano, Apologeticum 31, 1; 30, 4 (PL 1, cols 371-372): inspice Dei uoces, litteras nostras (...) scitote ex illis praeceptum esse nobis ad redundantiam benignitatis etiam pro inimicis deum orare et persecutoribus nostris boni precari (cf. Mt 5,44$)$.

${ }_{28}$ Tertuliano, Apologeticum 30, 1; 30, 4 (PL 1, cols 371-372: ...quia de pectore oramus, precantes sumus semper pro omnibus imperatoribus uitam illis prolixam, imperium securum, domum tutam, exercitus fortes, senatum fidelem, populum probum, orbem quietum, quaecumque hominis et caesaris uota sunt. 
suspensa pela trégua que foi acordada ao império romano. Tertuliano considerou que a vinda de Cristo trouxe uma suspensão concreta ao fim dos tempos e instalou uma moratória que terminará com o fim do que "está no meio", isto é, do poder romano. Tertuliano, nesta justificação, está a interpretar a 2 Thes. 2 6-8 "E agora vós sabeis o que O detém (a vinda do Senhor), pelo que ele só se manifestará no seu devido tempo. Porque o mistério da iniquidade já está em aç̧ão, esperando apenas o desaparecimento daquele que o impede $^{29}$ :

Uma outra razão, ainda mais importante, nos leva a rezar pelos imperadores, mas também pelo conjunto do universo, pela estabilidade do império e pelos interesses romanos: é que sabemos que o grande cataclismo que se abaterá sobre o universo, isto é, o fim do mundo, e que traz com ele horriveis sofrimentos, só está suspenso pela moratória (clausulam saeculi) concedida ao império romano. E como não queremos passar por essa experiência, quando rezamos pelo seu adiamento, favorecemos a continuação de Roma no tempo ${ }^{30}$.

A preservação do império romano é, para os que se reúnem nas assembleias, uma motivação para a prece, pelo que os cristãos comungam do interesse das autoridades romanas (Oramus etiam pro imperatoribus, pro ministeriis eorum et potestatibus, pro statu saeculi, pro rerum quiete, pro mora finis "rezamos também pelo imperador, pelos seus ministérios e pelas autoridades, pela estabilidade do mundo, pela paz das instituições, pela moratória do $\mathrm{fim}^{31}$.

Consideramos portanto que o discurso cristão sobre o domínio romano é, nos passos citados, favorável. Este não é, contudo, entendido como uma realidade absoluta. A aventura humana na terra conhecerá um fim, e está limitada por factores que não dependem dos homens, pelo que até o poderoso imperador depende dos desígnios divinos.

${ }^{29}$ Citamos a trad. portuguesa da Biblia dos Capuchinhos. (2 Thes 2, 6-8) Et nunc quid detineat scitis, ut reueletur in suo tempore. Nam mysterium iam operatur iniquitatis: tantum ut qui tenet nunc, teneat, donec de medio fiat.

${ }^{30} \mathrm{Op}$. cit. 32, 1 ...Est alia maior necessitas nobis orandi pro imperatoribus, et ita uniuerso orbe et statu imperii rebusque romanis, qui uim maximam uniuerso orbi imminentem ipsam clausulam saeculi acerbitates horrendas comminantem Romani imperii commeatu scimus retardari. Itaque nolumus experiri et, dum precamur differri, Romanae diuturnitatis fauemus.

${ }^{31}$ Op. cit. 39, 1; 2. W. Jones (op. cit., p. 381) considerou que apesar de o cristianismo, tal como o estoicismo, pregar uma mensagem de cosmopolitismo assente em noções de unidade moral e espiritual do universalismo, "The vast majority of Christian Romans identified the goals of the religion as identical with those of the state; and the ideals of Christianity were narrowed sharply to coincide with Roman ethnocentrism". 
Por isso, mesmo reconhecidas a lealdade e a identificação com o legítimo exercício do poder pelos romanos, este não deixa de ser concebido como uma realidade relativa, cuja duração os cristãos se limitam a favorecer pelo poder das suas preces ${ }^{32}$. Na verdade, não estamos muito longe do que Cícero afirmara em $O$ Sonho de Cipião, quando alertou para a vanidade do apego aos assuntos do mundo e para a relatividade e finitude de qualquer experiência humana, mesmo uma tão bem sucedida como a missão civilizadora dos romanos ${ }^{33}$.

Podemos, portanto, considerar que a mensagem evangélica e apostólica do universalismo, do mesmo modo que a fé na cidade celeste como destino metafísico dos cristãos apontado por Agostinho, abriu ao romano cristão as vias que, de algum modo, lhe permitiram superar a dolorosa perda de Roma como um fim absoluto.

\footnotetext{
${ }^{32}$ Ver n. 11.

${ }^{33}$ Ver n. 25.
} 